\title{
Efficacy and safety of remogliflozin etabonate in type 2 diabetes mellitus patients in a tertiary care hospital
}

\author{
Ameera Neelam, Anand Kanaki* \\ Department of Pharmacology, Mahadevappa Rampure Medical College, Kalaburagi, Karnataka, India
}

Received: 03 January 2021

Revised: 18 February 2021

Accepted: 02 March 2021

\author{
*Correspondence: \\ Dr. Anand Kanaki, \\ Email: anandkanaki@yahoo.com
}

Copyright: $(\odot$ the author(s), publisher and licensee Medip Academy. This is an open-access article distributed under the terms of the Creative Commons Attribution Non-Commercial License, which permits unrestricted non-commercial use, distribution, and reproduction in any medium, provided the original work is properly cited.

\begin{abstract}
Background: Incidence and prevalence of diabetes have been steadily increasing with a raise of global prevalence about $8.5 \%$. The major types of diabetes are differentiated by insulin deficiency versus insulin resistance. SGLT2 inhibitors are a new class of drugs that act by inhibiting glucose reabsorption in the proximal renal tubules. Remogliflozin a prodrug of remogliflozin, which is a potent and selective sodium-glucose co-transporter-2 inhibitor was used for the study. The objective of the study was to evaluate the efficacy and safety of Remogliflozin etabonate in reducing $\mathrm{HbA} 1 \mathrm{C}$ and serum glucose in type II diabetics.

Methods: This was a prospective observational study was done for 3 months. HbA1C, FBS and PPBS readings were noted and then the subjects were introduced to Remoglifozin $100 \mathrm{mg}$ twice a day. At the end of 12 weeks HbA1C, FBS and PPBS were noted. The obtained data was analysed for its efficacy and safety.

Results: The study included 22 male subjects and 28 females. Before Remoglifzoin was given the mean HbA1C level was $8.23 \pm 0.798$, mean FBS was $179 \pm 29.79$ and PPBS was $299.38 \pm 24.21$. Remoglifozin $100 \mathrm{mg}$ was given and the mean $\mathrm{HbA1C}$ level was $7.52 \pm 0.765$, mean FBS was $166.30 \pm 32.13$ and mean PPBS was 249.46 \pm 18.21 . Post 3 months of Remoglifzoin induction a reduction in HbA1C, FBS and PPBS was seen.

Conclusions: This study concludes Remoglifozin etabonate of $100 \mathrm{mg}$ when given twice daily reduced the $\mathrm{HbA1C}$ levels, FBS and PPBS levels significantly.
\end{abstract}

Keywords: Remoglifozin etabonate, Glycated hemoglobin test, Fasting blood glucose, Post prandial blood glucose

\section{INTRODUCTION}

Diabetes mellitus (DM) defined as "a set of similar metabolic disorders that have the same phenotype of hyperglycemia". ${ }^{2}$ The major types of diabetes are differentiated by insulin deficiency versus insulin resistance. ${ }^{1,2}$ Diabetes mellitus Type 1 (T1DM) caused by deficiency of insulin secretion because of pancreatic $\beta$-cell damage whereas Diabetes mellitus Type 2 (T2DM) is because of insulin resistance occurring at the level of liver, muscle (skeletal), and adipose tissue, with various levels of $\beta$-cell impairment. ${ }^{2}$ The number Diabetics increased from 108 to 422 million from year 1980 to 2014. Majority Diabetics are living in middle and low income countries, and 1.6 million human loss was directly attributed to diabetes each year Extra 2.2 million lives lost were attributable to high blood glucose in 2012. Both incidence and prevalence of diabetes have been steadily increasing over the past few decades. ${ }^{3-4}$ The global diabetes prevalence among adults $>18$ years of age was raised from $4.7 \%$ - $8.5 \%$ from year 1980 to $2014 .^{5}$ Diabetes is considered as a major/leading cause of death globally. ${ }^{6}$ Between 2000- 2016 five percent increase in mortality prematurely from diabetes was seen. ${ }^{3-4}$ Diabetes is a known leading cause of MI, kidney failure, blindness, cerebral stroke and amputations of lower limb. 3-4 Complications of Diabetes are classified into Microvascular that is due to involvement of small vessels 
and Macrovascular due to larger blood vessels involvement. ${ }^{7}$ SGLT 2 is the recent class of antihyperglycaemic agents approved. The SGLT2 inhibitors have a mechanism of decreasing renal glucose reabsorption and reduction of blood glucose without insulin release. ${ }^{8}$ Remogliflozin is administered in prodrug form viz. remogliflozin an immediate release (IR) tablet formulation. The recommended dosage for T2DM patients is $100 \mathrm{mg}$ twice daily. $\mathrm{RE}$ is rapidly and completely absorbed and available in the plasma within 10 minutes. ${ }^{9}$ This study was undertaken to assess the efficacy and safety of RE in our study setup.

\section{Aim and objective}

To evaluate the efficacy and safety of Remogliflozin etabonate in reducing $\mathrm{HbA} 1 \mathrm{C}$ and serum glucose in type II diabetics.

\section{METHODS}

\section{Study design}

Prospective study.

\section{Study setting}

The study was conducted in the Department of General Medicine at Basaveshwara Teaching and General Hospital attached to M.R. Medical College Kalaburagi.

\section{Study population}

All type II diabetics admitted/ on out-patient basis at Basaveshwara Teaching and General Hospital attached to M.R. Medical College.

\section{Study duration}

January 2020 to March 2020.

\section{Inclusion criteria}

Aged between 18- 65 years. Glycated haemoglobin $>6.5$ $\mathrm{mg} / \mathrm{dl}$. No co-morbidities (Pneumonia, MI, CVA and $\mathrm{UTI})$.

\section{Exclusion criteria}

Above 65 years and below 18. Severe moribund patients. On steroid therapy. Chronic kidney diseases

\section{Sample size}

No particular formula was used to define the sample size. Subjects who fulfilled the inclusion criteria were taken into the study. A total of 50 were enrolled for the study.

\section{Study procedure}

After obtaining consent from the subject's detailed history and clinical examination was noted using a pre-tested questionnaire. All the subjects were subjected to $\mathrm{HbA1C}$, FBS, PPBS tests and findings noted prior and post induction of Remoglifozin etabonate.

\section{Data collection tools}

All the relevant parameters were documented using a structured proforma. The proforma contained the following details- demographic parameters-like age, gender etc, medical illness-fever and other comorbid illness, ill Baseline parameters were checked (Pulse, BP, height, weight, BMI), clinical examination findings.

\section{Operational definitions $^{10}$}

HbA1C: >6.5 mg/dl, FBS: >126 mg/dl, PPBS: > 200 mg/dl

\section{Ethical issues}

Ethical clearance was obtained from the Institutional human ethical committee. Informed consent was obtained from each study participant, after explaining the risks and benefits involved in the study and voluntary nature of the participation, in a language participant could understand. Confidentiality of the study participants was maintained throughout the trial conduction and dissemination of the study results.

\section{Data entry and analysis}

The collected data was coded, entered into Microsoft excel work sheet and exported to SPSS. Data was analyzed using SPSS version 21. Data is presented as percentage in categories and then presented as tables. Paired t-test was used for test of significance.

\section{RESULTS}

A total of 50 subjects were included in the study. The age ranged between 21 to 65 years. Majority of the subjects were between 41 to 60 years. The mean age of the subjects was $49.58 \pm 10.05$ years. The study consisted of 22 male subjects and 28 females. For all the 50 subjects blood glucose parameters findings were noted before Remoglifzoin was given were the mean $\mathrm{HbA} 1 \mathrm{C}$ level was $8.23 \pm 0.798$, mean fasting blood glucose level was $179 \pm$ 29.79 and post prandial levels was $299.38 \pm 24.21$. All the 50 subjects were started on Remoglifzoin $100 \mathrm{mg}$ twice a day and after three months the blood glucose parameter levels were noted. The mean HbA1C level was 7.52 \pm 0.765 , mean fasting blood glucose was $166.30 \pm 32.13$ and mean postprandial levels was $249.46 \pm 18.21$. Post three months of Remoglifzoin induction a reduction in $\mathrm{HbA} 1 \mathrm{C}$, FBS and PPBS was seen (Table 1). Pre remoglifzoin and post Remoglifzoin was compared to assess the efficacy of Remoglifzoin. A highly significant value $(\mathrm{p}<0.001)$ was observed in the present study for all the three parameters (pre and post HbA1C, FBS and PPBS respectively) 
suggesting the Remoglifozin of $100 \mathrm{mg}$ when given twice daily reduced the HbA1C levels, FBS and PPBS levels significantly. No adverse effects like hypoglycemic events, fungal infection of genitials and urinary tract infections were observed among the subjects.

Table 1: Distribution of subjects.

\begin{tabular}{|c|c|c|c|}
\hline & Frequency & Percent & Mean \pm SD \\
\hline \multicolumn{4}{|c|}{ Age group (in years) } \\
\hline $21-30$ & 4 & 8 & \multirow{5}{*}{$49.58 \pm 10.05$} \\
\hline $31-40$ & 4 & 8 & \\
\hline $41-50$ & 16 & 32 & \\
\hline $51-60$ & 21 & 42 & \\
\hline$>60$ & 5 & 10 & \\
\hline \multicolumn{4}{|l|}{ Sex } \\
\hline Male & 22 & 44 & \\
\hline Female & 28 & 56 & \\
\hline \multicolumn{4}{|c|}{ Pre Remogliflozin } \\
\hline & Minimum & Maximum & Mean \pm SD \\
\hline $\mathrm{HbA} 1 \mathrm{C}$ & 6.7 & 9.7 & $8.23 \pm 0.798$ \\
\hline FBS & 130 & 230 & $179 \pm 29.79$ \\
\hline PPBS & 247 & 331 & $299.38 \pm 24.21$ \\
\hline \multicolumn{4}{|c|}{ Post Remoglifozin } \\
\hline & Minimum & Maximum & Mean \pm SD \\
\hline $\mathrm{HbA} 1 \mathrm{C}$ & 6.1 & 8.9 & $7.52 \pm 0.765$ \\
\hline FBS & 103 & 205 & $166.30 \pm 32.13$ \\
\hline PPBS & 222 & 282 & $249.46 \pm 18.21$ \\
\hline
\end{tabular}

Table 2: Pre Remogliflozin and post Remogliflozin effect on blood glucose parameters.

\begin{tabular}{|c|c|c|c|c|c|}
\hline \multirow{2}{*}{ Blood glucose parameters } & \multirow{2}{*}{ Mean } & \multirow{2}{*}{ SD } & \multicolumn{2}{|c|}{$95 \% \mathrm{CI}$} & \multirow{2}{*}{ P value } \\
\hline & & & Lower & Upper & \\
\hline $\begin{array}{l}\text { Pre remoglifozin } \mathrm{HbA1C} * \text { post } \\
\text { remoglifozin } \mathrm{HbA1C} \text { levels }\end{array}$ & 0.7100 & 0.4282 & 0.5883 & 0.8317 & $<0.001^{\#}$ \\
\hline $\begin{array}{l}\text { Pre remoglifozin FBS* post } \\
\text { remoglifozin FBS levels }\end{array}$ & 13.180 & 9.9954 & 10.351 & 16.009 & $<0.001^{\#}$ \\
\hline $\begin{array}{l}\text { Pre remoglifozin PPBS* post } \\
\text { remoglifozin PPBS levels }\end{array}$ & 49.920 & 9.319 & 47.271 & 52.569 & $<0.001^{\#}$ \\
\hline
\end{tabular}

\section{DISCUSSION}

The mean age of the present study was $49.58 \pm 10.05$ years which was consistent with a study done by Mala et al. which showed a mean age of $50.86 \pm 8.76$ years. ${ }^{11}$ Study by Pattanaik consisted of 28 males and 22 females whereas the present study consisted of 22 males and 28 females. $^{12}$ Mohan et al in their study suggested HbA1C decrease when above $100 \mathrm{mg}$ a day was given which consistent with the present study were the $\mathrm{HbA} 1 \mathrm{c}$ was $7.52 \mathrm{mg} / \mathrm{dl}$ which showed efficacy and safety of Remoglifozin for the 12 week study period. 13 Also Mala et al suggested in their study a significant $(\mathrm{p}<0.001)$ reduction in HbA1C levels. 11 Mohan et al suggested a reduction of mean FBS by 23.2 $\mathrm{mg} / \mathrm{dl}$ when $100 \mathrm{mg}$ of Remoglifozin was given twice a day which was near to consistent with the present study i.e $32.13 \mathrm{mg} / \mathrm{dl} .{ }^{13}$ Study by Dobbins et al also concluded Remoglifozin has good effect in decreasing FBS. ${ }^{14}$ Mala et al in their study showed a reduction of mean PPBS of 17.86 $\mathrm{mg} / \mathrm{dl}$ which was also seen in the present study i.e 18.21 $\mathrm{mg} / \mathrm{dl} .^{11}$

\section{CONCLUSION}

Remoglifozin Etabonate therefore can be a contemplate for effective alternate/substitute treatment for control of glycaemia in type II diabetics.

\section{Funding: No funding sources}

Conflict of interest: None declared

Ethical approval: The study was approved by the Institutional Ethics Committee

\section{REFERENCES}

1. Longo D, Kasper DL, Fauci AS, Hauser S, Jameson JL, Loscalzo J et al, editors. Harrison's principles of 
internal medicine, 19th ed. New York: The McGrawHill Companies, Inc. 2015.

2. Weber DR, Jospe N. Diabetes Mellitus: Classification of Diabetes MellitusIn: Kliegman, Behrman, Jenson, editors, Nelson Textbook of Pediatrics. 21st edition, New Delhi: Elsevier. 2020;2:11814-11936.

3. World health organization. Diabets- health topics. Geneva, 8 June 2020. https://www.who.int/healthtopics/diabetes\#tab=tab_1. Accessed on 13th July 2020.

4. World health organization. Diabets- key facts. Geneva, 8 June 2020. https://www.who.int/newsroom/fact-sheets/detail/diabetes. Last accessed on 13th July 2020.

5. Sarwar N, Gao P, Seshasai SR, Gobin R, Kaptoge S, Di Angelantonio et al. Diabetes mellitus, fasting blood glucose concentration, and risk of vascular disease: a collaborative meta-analysis of 102 prospective studies. Emerging Risk Factors Collaboration, Lancet Publication. 2010;26(375):2215-2222.

6. Saran R, Li Y, Robinson B, Ayanian J, Balkrishnan R, Jennifer BG et al. US Renal Data System 2014 Annual Data Report: Epidemiology of Kidney Disease in the United States. Am J Kidney Dis. 2015;66(3):545.

7. World health organization. Diabetes ProgrammeAbout diabetes-Complications of diabetes. Geneva, June 2020. Available at: https://www.who.int/ diabetes/action_online/basics/en/index3.html. Last accessed on 13th July 2020.

8. Curr Opin Endocrinol Diabetes Obes. 2017;24(1):7379.

9. Kapur A, O’Connor-Semmes R, Hussey EK, Robert LD, Wenli T, Marcus $H$ et al. First human doseescalation study with remogliflozinetabonate, a selective inhibitor of the sodium-glucose transporter 2
(SGLT2), in healthy subjects and in subjects with type 2 diabetes mellitus. BMC Pharmacol Toxicol. 2013;14(1):26.

10. Type II diabetes diagnostic criteria by American diabetic association. Updated: Feb 2020.

11. Mala D, Thacker SRA, Paramesh S, Mohan B, Chawla $M$ et al. Efficacy and Safety of Remogliflozin Etabonate, a New Sodium Glucose Co-Transporter-2 Inhibitor, in Patients with Type 2 Diabetes Mellitus: A 24-Week, Randomized, Double-Blind, Active-Controlled Trial.

12. Pattanaik SR. Efficacy of Addition of Remogliflozin to Type-2 Diabetic Patients, Uncontrolled with Dual Drug Treatment with Metformin and Glimeperide, an Observational Study. International Journal of Contemporary Medicine Surgery and Radiology. 2020;5(3):1-3.

13. Mohan V, Mithal SR, Joshi SR, Aravind, Chowdhury S. Remogliflozin Etabonate in the Treatment of Type 2 Diabetes: Design, Development, and Place in Therapy. Dovepress Journal. Drug Design, Development and Therapy. 2020;14:2487-250.

14. Dobbins RL, O’Connor-Semmes R, Kapur A, Kapitza C, Golor G, Mikoshiba I, et al. Remogliflozin etabonate, a selective inhibitor of the sodiumdependent transporter 2 reduces serum glucose in type 2 diabetes mellitus patients. Diabetes Obes Metab. 2012;14:15-22.

Cite this article as: Neelam A, Kanaki A. Efficacy and safety of remogliflozin etabonate in type 2 diabetes mellitus patients in a tertiary care hospital. Int J Basic Clin Pharmacol 2021;10:353-6. 